http://www.jfas.info

\title{
INTENSITY AND EFFICIENCY ANALYSIS OF ASSETS USE WHEN MONITORING THE GOODWILL IN THE CONTROLLING SYSTEM
}

\author{
L. I. Kulikova*, E. Yu. Vetoshkina, R. R. Nurgatin \\ Institute of Management, Economics and Finance of Kazan Federal University, 4, Butlerova \\ street, Kazan, Russia
}

Published online: 15 February 2017

\begin{abstract}
The article presents the statistical evidence of a considerable gap between the market value of a modern company and the carrying value of its net assets. The authors define the gap as an underestimated part of assets and identify it with the company's goodwill. The authors research the practical application area of the business activity indicators, including for the grounded management decisions concerning the evaluation of investment attractiveness and efficiency of assets utilization of the modern companies.
\end{abstract}

Keywords: goodwill, business activity, intangible assets, profitability, financial statements

\section{INTRODUCTION}

The high goodwill is important for any company; this is defined its study relevance, particularly in the context of the growing rates of integration of the Russian economy with the international market. The impeccable company's goodwill simplifies the access to the financial, labor and information sources, provides the highest business protection and the opportunity to effectively influence the structure of industrial markets. In addition, the goodwill allows obtaining the long-term loans at minimal interest. In theory, the goodwill is inversely proportional to the risks affecting the company's performance and is directly proportional to the capitalization of its assets and solvency ratios.

Author Correspondence, e-mail: author@gmail.com

doi: http://dx.doi.org/10.4314/jfas.v8i2s.636 
The positive company's goodwill also can help it:

- to give more psychological value to the products and services;

- to attract new customers when they face the choice between the functionally similar goods or services;

- to attract the most competent staff in the company and increase the job satisfaction of the existing staff;

- to enhance the effectiveness of advertising and sales, to support the distributors, advertising agencies, suppliers, and business partners;

- to concentrate the funds on the stock market and survive in the crisis situation.

The company is operating in the situations of varied relationships when each party has its own economic, social and other interests. Certainly, the control of impacts affecting the company both inside and outside is one of the most important functions, which ensures the company's well-being. The flexibility of the interaction and feedback are the processes associated with the achievement of the company's goals. The main tasks performed as a part of this activity are the image cultivation, development of the trust relationships with customers and suppliers and the high goodwill building-up.

Until the 1980s, the market value of the foreign corporations was comparable to their net assets carrying the value as the income of the companies was depended only on the value of the tangible assets under their control. By the early 1980s, there has been a growing gap between the market and carrying value of the corporations under the conditions of the global introduction of the automated control systems and enhancing the role of intangible assets in the profit generation.

In December 2007, the company Brand Finance published the study [1], in which a representative sample of the world largest public companies was studied (Fig. 1). In particular, it was noted in the EBRC's report that about $75 \%$ of such companies' value at that moment was not disclosed in their public financial statements. We note that the mentioned ratio of the company's value composition was broken by the financial crisis of 2008 , but every year is aligning and coming to the same values; moreover, in the context of the ongoing production intensification as well as the increasing role of the technological development, it is correct to assume that the share of assets not reflected in the financial statements may increase in the near future. 


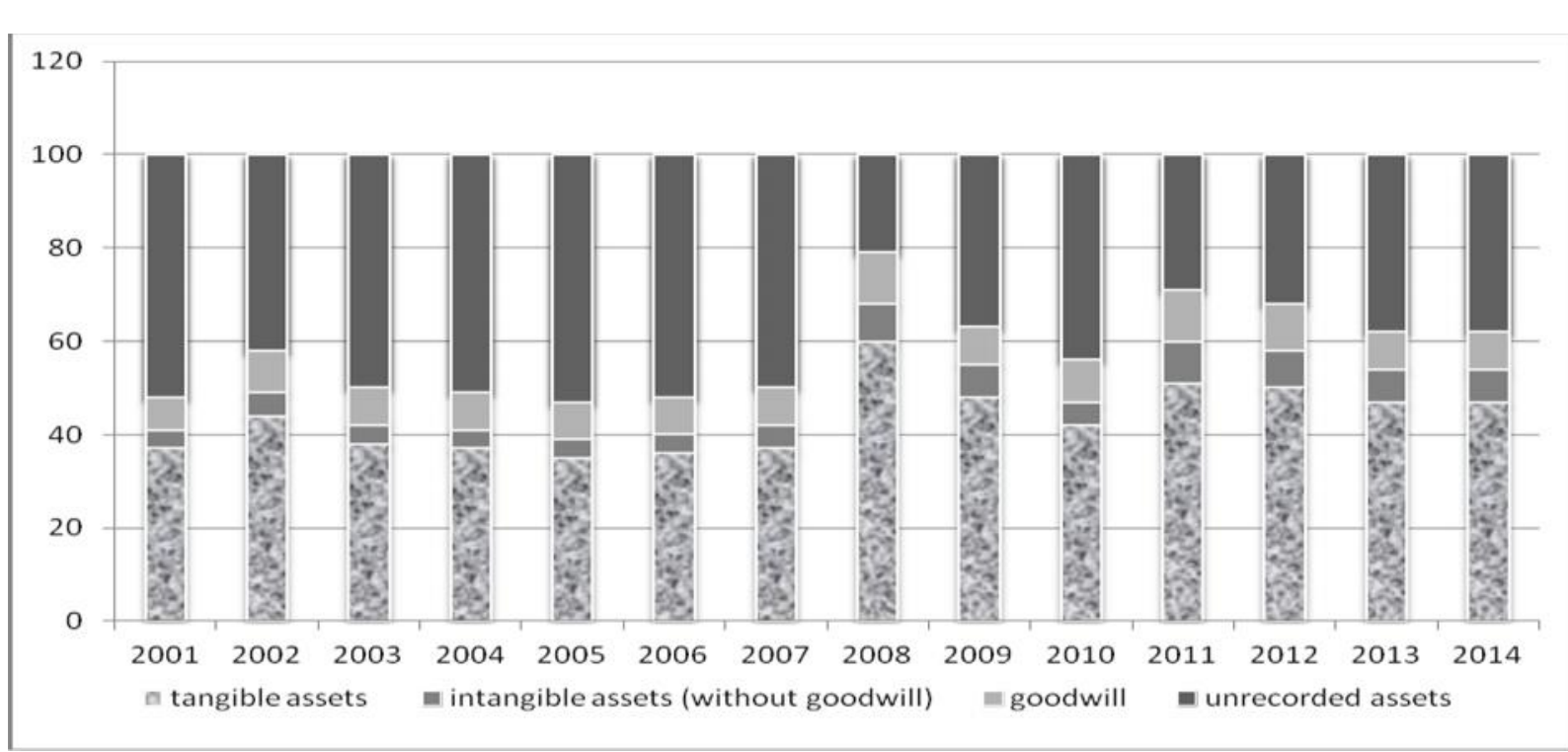

Fig.1. The global composition of the companies' value \% [1]

\section{Theory}

Currently, the information only about $35 \%$ of the assets composing the company's market value is disclosed in the "classical" financial statements under IFRS or FASB. Consequently, the potential investor could only guess as a result of what benefits the market value of such company exceeds the carrying value of its assets by more than a half.

These conclusions are supported by the researches conducted by one of the leading international auditing companies Ernst \& Young [2]. So, in 2007, the statistics of 709 mergers and acquisitions around the world was studied. As a result, it was found that only $30 \%$ of the purchase price on average is the cost of its tangible assets. Another $23 \%$ of the company's value may be allocated to the share of identifiable intangible assets such as brands, contracts with customers and technologies. The remaining share of $47 \%$ of the company's market value is recognized as goodwill.

In this regard, we note that, to the wide extent, the company's intangible value growth reflects the investments that have been made by it in the computer systems, personnel training, process automation, branding improvement, as well as in research and development in the last ten years. In 1985, the real investments exceeded the investments in the intangible assets by $40 \%$, in 1995 , this ratio was 50/50, in 2007, the intangible investments exceeded the share of real investments by 33\% [3]. This information gap is known, but the problem of nondisclosure of considerable value of the modern company in the financial statements is still not fully resolved. This statistic is also noted in the researches of 2008 by such authors as Y. 
Ding, J. Richard, H. Stolowy [4], later, in 2010, by G. Liberatore, and F. Mazzi [5], in 2011, by C. Lee [6], W. Xu, A. Anandarajan, and A. Curatola [7].

The theoretical and methodological framework of the analysis and evaluation of the business activity was studied in the works of T. Brinck [8], K.W. Chauvin, and M. Hirschey [9], J. Abdul Majid [10], E. Yu. Vetoshkina, R.S. Tukhvatullin [11], and others.

To maintain the value of unrecorded assets in the balance sheet, the permanent analysis of the intensity and efficiency of the company's assets use is required. When monitoring the goodwill changes in the controlling system, it is necessary to select the key indicators. Such indicators often include the turnover ratios of assets and liabilities, turnover duration in days, operating cycle duration (sum of inventory and receivables turnover periods).

Nevertheless, the profitability is an integral part of the system of performance indicators of the companies. In the classical analysis, the business activity is mostly associated with turnover; in turn, the individual turnover ratios are rarely used as the analysis objects, however, they are involved in the profitability analysis models describing the invested funds turnover rate.

The profitability is an assessment of the funds use, in which the company not only covers its costs by income but generates the profit. The profitability ratios are much less subject to inflation than the absolute profit because they are characterized by various ratios of profit and prepaid assets (capital) or profits and different expenses. When analyzing the calculated profitability ratios, they should be compared to the planned and comparative targets, as well as to the statistics of other companies in the industry.

The profitability ratios are the key efficiency indicators of the company and its activities. The profitability ratios are the relative indicators, i.e. they represent the ratio of income to the activity types, sales volumes, the amount of property, etc. The profitability ratios analysis is performed using the study of historical changes, trends, and rates.

Return on assets (ROA) describes how much net profit is accounted for 1 ruble of assets, in other words, what is the profitability of the company's assets. Return on assets shows the company's managers performance and the effectiveness of the decisions taken by the management and owners of the company (organization).

To calculate and analyze return on assets, the following formula is used:

$$
R \mathrm{a}=\frac{\mathrm{PBT}}{\text { Aaver }} * 100=\frac{\mathrm{PBT}}{\text { Vsales }} * \frac{\text { Vsales }}{\text { Aaver }} * 100
$$


where:

$\mathrm{R}_{\mathrm{a}}$ is return on assets;

PBT is profit before tax;

aver is annual average assets value;

$\mathrm{V}_{\text {sales }}$ is sales revenue.

In this equation, the first multiplier represents the sales efficiency in terms of weight of trade margins in one ruble of the selling price; the second multiplier is the rate of return on assets in the form of revenue.

Return on assets is applied to define the efficiency of their use in the company. The both factors in the model have a strong impact on the business activity and are deserved the careful attention of the company's management.

We consider the impact of individual factors influencing the indicator of business activity mentioned above:

First of all, the company should define at the expense of what factors return on assets growth will be ensured to a greater extent:

a) the sales efficiency in terms of weight of trade margins in one ruble of the selling price is more indicative for companies with relatively inelastic price-dependent demand.

b) the rate of return on assets in the form of revenue is typical for large companies selling the consumer goods with a fairly low trade margin in one ruble of sales.

For analytical purposes, return on fixed assets is also defined in addition to return on total assets.

Return on fixed assets is applied to assess and analyze the effectiveness of the use of fixed assets in the company. For factor analysis of return on fixed assets, it is necessary to decompose the original formula by qualitative characteristics.

$$
\mathrm{R}_{\mathrm{PPE}}=\frac{\mathrm{PBT}}{\text { PPEaver }+ \text { CAaver }}=\frac{\frac{\mathrm{PBT}}{\mathrm{VSales}}}{\frac{\text { PPEaver }}{\text { Vsales }}+\frac{\text { CAaver }}{\text { Vsales }}}=\frac{\mathrm{Pr}}{\mathrm{CI}+\mathrm{Ra}_{\mathrm{a}}},
$$

where:

$\mathrm{R}_{\mathrm{PPE}}$ is return on fixed assets;

PBT is profit before tax; 
$\mathrm{PPE}_{\mathrm{aver}}$ is average value of fixed assets;

$\mathrm{CA}_{\text {aver }}$ is average balances of current assets;

$\mathrm{V}_{\text {sales }}$ is sales revenue;

$\mathrm{P}_{\mathrm{r}}$ is the company's profitability;

CI is capital intensity;

$\mathrm{R}_{\mathrm{a}}$ is allocation ratio.

It is necessary to divide the indicator components in sales revenue. On rearrangement, return on fixed assets will be determined by the ratio of sales profitability in the numerator and capital intensity and allocation ratio in the denominator. To evaluate the business activity, return on fixed assets is calculated with the aim to define the efficiency of their use. We consider the impact of individual factors on the business activity indicator.

As a rule, the decrease of allocation ratio has a significant positive impact on the business activity of the company due to increase in the current assets turnover rate. In this regard, the company's management should pay careful attention to its dynamics and value.

In our opinion, the capital intensity indicator should not be considered as a direct indicator describing the business activity of the company. It will be a mistake to consider the growth of fixed assets during the reporting period as a reserve of the immediate output increase since it is often associated with the reproduction of technological equipment. Also, the capital intensity indicator loses its relevance during fixed assets modernization due to its overstatement.

Return on equity shows the profit from each money unit invested by the equity owners. It is the underlying factor which defines the efficiency of investments in any activity. For factor analysis of return on equity, it is necessary to decompose the original formula by qualitative characteristics as follows:

$$
\operatorname{Re}=\frac{\mathrm{NP}}{\text { Eaver }} * 100=\frac{\mathrm{NP}}{\text { Caver }} * \frac{\text { Caver }}{\text { Eaver }}=\frac{\mathrm{NP}}{\text { Vsales }} * \frac{\text { Vsales }}{\text { Caver }} * \frac{\text { Caver }}{\text { Eaver }} * 100 \text {, }
$$

where:

Re is return on equity;

NP is net profit;

Eaver is annual average equity value;

Caver is annual average total capital value;

Vsales is sales volume; 
- profitability of sales on net profit;

- capital turnover;

- capital multiplier.

Thus, return on equity depends on the profitability of sales on net profit, capital turnover, and capital multiplier change.

Return on equity is applied to define the efficiency of its use in the company. All the factors in the model have a strong impact on the business activity and are deserved the careful attention of the company's management.

We consider the impact of the factors on the business activity indicator:

a) the analysis of the profitability of sales on net profit and capital turnover has a high relevance in the analysis of the business activity. These factors are considered in detail earlier in the factor analysis of return on assets.

b) the capital multiplier deserves a great attention in the analysis of the business activity. The company's owners should define the regulated values of financial leverage based on the company's policy for the acceptable level of risk and return. In practice, the bonuses of managers often depend on net profit in the reporting period.

If the company is not able to generate the necessary profit to pay the bonus at the end of the year, a manager begins to increase the share of borrowings and through the lever arm gets a high profit.

But the data manipulation with capital is associated with great risk. Under the conditions of the declining return on assets due to the crisis and sanctions, as well as increase in the average interest rates on the borrowings in connection with the ruble depreciation, the company can sustain huge losses and even bankrupt due to the negative differential and large lever arm.

\section{RESULTS}

For the integrated evaluation of the goodwill through indicators of the business activity, we suggest using the developed model: 
Table 1. The model of measuring the intensity and efficiency of assets use when monitoring the goodwill of the oil company Oil-plus Ltd.

\begin{tabular}{|l|c|c|c|c|}
\hline \multicolumn{1}{|c|}{ Indicators } & $\begin{array}{c}\text { Return on } \\
\text { assets (ROA) }\end{array}$ & $\begin{array}{c}\text { Return on fixed } \\
\text { assets }\end{array}$ & $\begin{array}{c}\text { Return } \\
\text { on equity }\end{array}$ & $\begin{array}{c}\text { business } \\
\text { activity in } \\
\text { points }\end{array}$ \\
\hline $\begin{array}{l}\text { 1.1. Indicator value for 2013 } \\
\text { 1.2. Indicator value for 2014 }\end{array}$ & 0.0789 & 1.3043 & 0.4292 & $\mathrm{X}$ \\
\hline $\begin{array}{l}\text { 1.3. Indicator value for 2015 } \\
\text { account of the discount rate }\end{array}$ & 0.0661 & 1.3578 & 0.3710 & $\mathrm{X}$ \\
\hline $\begin{array}{l}\text { 2.2. Indicator value for 2014 with } \\
\text { account of the discount rate }\end{array}$ & 0.0029 & 0.0585 & 0.0091 & $\mathrm{X}$ \\
\hline $\begin{array}{l}\text { 2.3. Indicator value for 2015 with } \\
\text { account of the discount rate }\end{array}$ & 0.0601 & 1.2344 & 0.3373 & $\mathrm{X}$ \\
\hline $\begin{array}{l}\text { 3.1. The ratio of the discounted } \\
\text { indicator value for 2014 to the } \\
\text { value for 2013 }\end{array}$ & 0.0372 & 0.0448 & 0.0212 & 0.10 \\
\hline $\begin{array}{l}\text { 3.2. The ratio of the discounted } \\
\text { indicator value for 2015 to the } \\
\text { value for 2014 }\end{array}$ & 18.6010 & 19.1875 & 33.7300 & 71.52 \\
\hline
\end{tabular}

The indicators discussed earlier are filled in table 1 in the lines 1.1-1.3. The lines 2.12.3 are discounted values of the lines 1.1-1.3 for the purpose of cash flows reduction to the same time value. The lines 3.1-3.2 contain the ratio of the discounted indicator value of the reporting year to its base value. The obtained relative values or points will vary between 0 and 10 , and in rare cases even more, although, in practice, the company is unlikely to be able to achieve value in 2 points because in this case, it should increase the value of its indicator more than twofold. 
Table 2. The monitoring results of the company's business activity changes Oil-plus Ltd.

\begin{tabular}{|c|c|c|c|c|}
\hline $\begin{array}{l}\text { Change in the } \\
\text { business activity }\end{array}$ & $\begin{array}{l}\text { Value in } \\
\text { conditio } \\
\text { nal units }\end{array}$ & $\begin{array}{l}\text { Evaluati } \\
\text { on } \\
\text { criterion }\end{array}$ & Short-term period & Long-term period \\
\hline in 2014 & -2.9 & $<=0$ & $\begin{array}{l}\text { Business activity } \\
\text { decline }\end{array}$ & $\begin{array}{l}\text { Decrease of the goodwill } \\
\text { and the total value of the } \\
\text { company }\end{array}$ \\
\hline in 2015 & 68.5 & $>=0$ & $\begin{array}{l}\text { Business activity } \\
\text { increase }\end{array}$ & $\begin{array}{l}\text { Goodwill will increase, the } \\
\text { total value of the company } \\
\text { also will increase }\end{array}$ \\
\hline
\end{tabular}

Table 2 shows the changes in the business activity; for this purpose, we use the value of the business activity that we calculated in table 1 . Then we take 3 from the value and get the change in the business activity. We use number three as a base, as it reflects the situation, when the indicators compared with the previous year remained at the same level with the account of the cash flows discounting.

When the value of the change in the business activity is zero, it can be concluded that the activity and goodwill are at the stable level.

In the case of negative change, we have seen the negative trend, when the activity and goodwill are decreasing and the company loses a share of its value in the long-term period. The positive change in the business activity is favorable, the activity and goodwill increase as well as total capitalization.

We have tested the model described above according to the data of the oil company Oil-plus Ltd. Based on the financial statements for 2013-2015, we have developed the model for intensity and efficiency analysis of assets use when monitoring the goodwill.

In 2014, the company considerably decreased the business activity compared to 2013. So, even without the discounting, return on assets ratio declined by $96 \%$, return on fixed assets - by $95 \%$, return on equity - by $98 \%$. This decrease is due to the imposition of sanctions on the Russian oil companies and the volatility of the ruble exchange rate. So, in 2014, the exchange losses amounted to about RUB 1.2 billion and the revenue declined by RUB 2 billion. 
In 2015 , the value of the change in the business activity was 68 conditional units. Compared to 2014 , the company increased its return on assets and fixed assets by $95 \%$, return on equity - by $97 \%$.

At first sight, it can be concluded that the company had greatly improved its performance and increased its goodwill at an extreme rate, but the competent economist should study the financial indicators in an integrated manner and take into account all available information.

This example clearly shows us that, when monitoring the business activity, we do not uselessly analyze the several reporting periods at once in our model. If we compare the figures for 2015 with the figures for 2013, even without taking into account the time value of money, the results for 2013 are still higher than values for 2015. However, it should be noted that the company has coped with the crisis of 2014 and recover the previous financial indicators. From the point of view of the management and the company's owners, there is a positive trend and it is necessary not to slow down the sustained business development.

\section{CONCLUSION}

The main criterion of the effectiveness of the company's current activity is the indicators of its business activity. In the long-term period, the business activity is transformed into the category of goodwill. The companies with high goodwill have more positive values of the business activity indicators.

To justify the made hypotheses about the categories relationship, the theoretic content of the business activity category was studied, the aspects of the practical application of the business activity indicators in the process of investment attractiveness and efficiency evaluation were considered. The developed model of measuring the intensity and efficiency of assets use when monitoring the goodwill was tested in the oil company Oil-plus Ltd.

The need for the comprehensive approach to the monitoring of the business activity, not the analysis of the individual economic indicators is explained by the fact that the business activity is possible to be objectively evaluated only through the integrated analysis.

The business activity of the industry and economy as a whole depends in total on the business activity and goodwill of the individual companies. Just the business activity of the companies is the engine of the social and economic progress in the market economy.

The global financial crisis and sanctions imposed against our country led to the industrial production decline. The settlement problems throw into sharp relief when the nonpayments crisis is constant. The own financial resources of the industrial companies are 
reduced, the profitability decreases. These and many other factors put the industrial companies in the complex survival situation.

Currently, improving the competitiveness of the business entities is a vital goal, so the managers are constantly looking for new management and competitiveness improvement tools. The increased market competition pushes the companies to look for new forms and methods of competition. In the market economy, the companies should aim at the dynamic, effective and rational development, which is impossible without the business activity management, the ultimate goal of which is to increase the competitiveness of the business entity.

\section{REFERENCES}

1. Brand Finance: www.brandfinance.com. Look for various publications, in particular the various "Intangible Trackers" and brand value reports.

2. Ernst \& Young: http://www.ey.com. Acquisition accounting - What is next for you?

3. The association of accountants and financial professionals in business http://www.imanet.org/ Unrecognized Intangible Assets Identification, Management and Reporting

4. Ding, Y., Richard, J. \& Stolowy, H., 2008. Towards an understanding of the phases of goodwill accounting in four Western capitalist countries: From stakeholder model to shareholder model. Accounting, Organizations and Society, 33(7-8),pp.718-755.

Available at:http://www.sciencedirect.com/science/article/pii/S0361368207000505 [Accessed December 7, 2015].

5. Liberatore, G. \& Mazzi, F., 2010. Goodwill write-off and financial market behaviour: An analysis of possible relationships. Advances in Accounting, 26(2), pp.333-339. Available at:http://www.sciencedirect.com/science/article/pii/S0882611010000350 [Accessed December 7, 2015].

6. Lee, C., 2011. The effect of SFAS 142 on the ability of goodwill to predict future cash flows. Journal of Accounting and Public Policy, 30(3), pp.236-255.

Available at:http://www.sciencedirect.com/science/article/pii/S0278425410000979 [Accessed December 7, 2015].

7. Xu, W., Anandarajan, A. \& Curatola, A., 2011. The value relevance of goodwill impairment. Research in Accounting Regulation, 23(2), pp.145-148. Available 
at:http://www.sciencedirect.com/science/article/pii/S1052045711000361

[Accessed

December 7, 2015].

8. Brinck, T., 2005. Cost-Justifying Usability, Elsevier. Available at: http://www.sciencedirect.com/science/article/pii/B9780120958115500134

[Accessed December 7, 2015].

9. Chauvin, K.W. \& Hirschey, M., 1994. Goodwill, profitability, and the market value of the firm. Journal of Accounting and Public Policy, 13(2), pp.159-180.

Available at: http://www.sciencedirect.com/science/article/pii/0278425494900183 [Accessed December 7, 2015].

10. Abdul Majid, J., 2015. Reporting incentives, ownership concentration by the largest outside shareholder, and reported goodwill impairment losses. Journal of Contemporary Accounting \& Economics, 11(3), pp.199-214. Available at: http://www.sciencedirect.com/science/article/pii/S1815566915000247 [Accessed November 4, 2015].

11. Vetoshkina E. Yu., Tukhvatullin R.Sh, 2015. Economic Efficiency Estimation of Intangible Assets Use/ E.Yu. Vetoshkina, R.Sh. Tukhvatullin// Mediterranean Journal of Social Sciences, Vol 6, No 1 S3 (2015): February 2015, p. 440-443.

\section{How to cite this article:}

Kulikova L I, Vetoshkina E Yu, Nurgatin R R. Intensity and efficiency analysis of assets use when monitoring the goodwill in the controlling system. J. Fundam. Appl. Sci., 2017, 9(1S), 2031 . 